\title{
Inventory decision-making by small Sowetan retailers
}

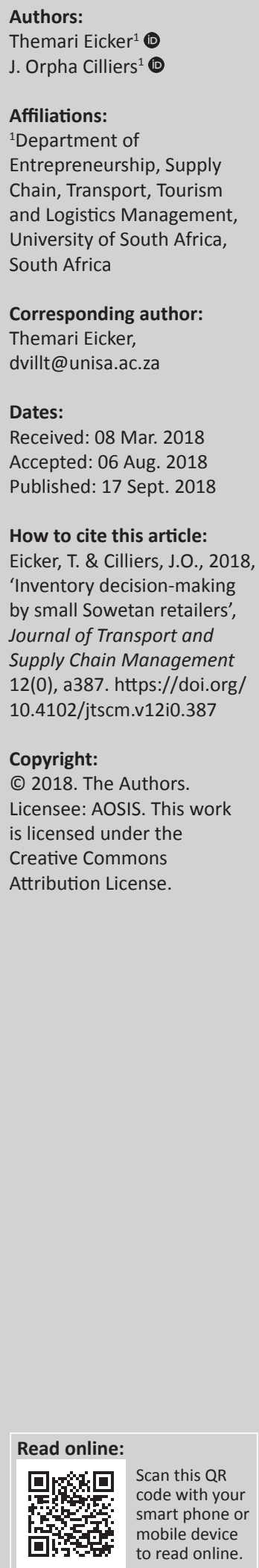

Background: The importance of South African small businesses, especially retailers, in improving communities' standards of living necessitates sound business strategies to survive and remain competitive. Selecting appropriate business strategies is cardinal for the sustainable development and growth of all types of businesses, including small businesses. The supply chain strategy defines how operations in the supply chain will support the overall competitive strategy and is orientated to promote either responsiveness or cost-efficiency. It is imperative that all inventory decisions be aligned with the orientation of the selected supply chain strategy.

Objectives: The aim of this article was firstly to determine how small retailers operating within the boundaries of Soweto, a township in Gauteng, South Africa, manage their inventory decisions considering the orientation of the supply chain strategy; and secondly, to investigate whether retail industries differ in terms of inventory decisions.

Method: A survey was conducted among 650 formal, independent small businesses operating within Soweto of which 556 were classified as retailers based on the Standard Industrial Classification. Structured interviewer-completed questionnaires were used to obtain quantitative data from owners or managers. Both descriptive and inferential analyses were performed to determine the orientation of the retailers' supply chain strategy based on their inventory decisions relating to the average rate of purchasing inventory, the amount of inventory purchased, as well as the quality and variety of products offered to customers. Five hypotheses were formulated to determine whether a difference exists between six industry groups with regard to the management of inventory.

Results: It was established that small township retailers predominantly manage their inventory decisions responsively. It was also concluded that differences exist in terms of how small township retailers manage their inventory based on the industry in which they operate. The results showed that retail hardware stores are focused on making inventory decisions more cost-efficiently than the other industry groups, whereas retail general stores are focused on making inventory decisions more responsively than the other industry groups.

Conclusion: The owners or managers of small township retailers need to be educated in terms of inventory management decisions. This article can be used as an educational platform to show how small township retailers can identify the aligned inventory decisions for supporting a selected supply chain strategy orientation. Generally, small township retailers may maintain their competitive advantage if they align all business strategies to promote responsiveness. Since the industry in which small retailers operate influences inventory management decisions in terms of responsiveness and cost-efficiency, owners or managers must consider the specific industry in which they operate before making such decisions.

\section{Introduction}

Inventory is one of the most expensive assets within a business and should be managed effectively - which implies that the right amount of inventory is purchased at the right price and time to support the business's day-to-day activities (Monczka et al. 2016:621-622; Wisner, Tan \& Leong 2016:209). Inventory refers to all goods in motion and at rest within a supply chain and is kept to address the imbalance between the supply and demand of products (Chopra \& Meindl 2016:61; Coyle et al. 2013:636). Even with intangible services that cannot be stored, physical products are often needed in facilities where the service is rendered (Bowersox et al. 2013:37; Lawrence, Sivakumar \& Arivarignan 2013:4771). As with all management decisions, inventory decisions should be aligned with the competitive strategy and different functional strategies (of which the supply chain strategy forms part of) (Chopra \& Meindl 2016:35-37). Such an alignment requires that the type of product (or service) offering forms the starting point when 
crafting the supply chain strategy. Selecting appropriate business strategies is cardinal for the sustainable development and growth of all types of businesses, including small businesses (Leitner \& Güldenberg 2010:185). The supply chain strategy defines how operations in the supply chain will support the overall competitive strategy (Ambe 2012:126) and stipulates the specific plan of action for integrating suppliers, manufacturers, warehouses and retail stores. The supply chain guides the process of ensuring that inputs are purchased and that products are produced and distributed in the correct quantities, at the right time and to the right location. This strategy is implemented while balancing overall costs and satisfying customers' service-level requirements (Qrunfleh \& Tarafdar 2013:571).

Retailers should analyse individual consumer needs within their industry to ensure that they offer their target market corresponding products (and services) at preferred outlets (Huddleston et al. 2009:66). This willingness of the retail sector to provide consumers with choices in terms of products (and services) for need-satisfaction contributes to communities' economic and social welfare and well-being (Ligthelm 2008:37). Thus, the value-adding role of retailers, as the final link in the supply chain, lies in offering an assortment of products (and services) to their customers in the right quantity at a convenient location (Ligthelm 2008:38; Prinsloo 2014:1). Hatten (2012:165) concludes that in their attempt to provide value to the customer, small retailers mainly compete on operational excellence (by asking the best or lowest price), product leadership (by offering the best product of a high quality) and customer intimacy (by offering the best service). In serving their markets, small business retailers' decisions on their market offering should revolve around sustaining their competitive advantage as encapsulated within their business strategies.

This article investigates the inventory decisions made by South African small retailers according to their supply chain strategy orientation.

\section{Problem statement}

In the post-apartheid period (after 1994), the new South African government immediately prioritised the development of black-owned businesses as part of developing the South African small business economy, which included the development of small businesses in townships (Rogerson \& Rogerson 1997:33). Although the Gauteng Department of Economic Development acknowledged that government had implemented numerous initiatives and development plans aimed at developing townships into liveable and vibrant economic centres, they stated that townships were unfortunately still operating within an unpredictable business environment characterised by low levels of entrepreneurial activities, low survival rate for small businesses and a lack of business skills by the owners or managers of these businesses (Gauteng Department of Economic Development 2014:4-5). For the purpose of this article, the definition of a small business as defined by the National Small Business
Amendment Act of 2004 (South Africa 2004) is accepted, which reads that a small business is:

a separate and distinct business entity, together with its branches or subsidiaries, if any, including co-operative enterprises and non-governmental organisations, managed by one owner or more which, including its branches or subsidiaries, if any, is predominantly carried on in any sector or subsector of the economy and which can be classified as a micro-, a very small, a small or medium enterprise. (n.p.)

Alas, small businesses have either a limited number of individuals taking responsibility for strategic decisions or a lack of educated and skilled employees (owners or managers), which results in strategic decisions often being made informally by the owners or managers based on personal opinions, often detrimental to business success (Walker et al. 2007:295). Small business owners or managers tend to make haphazard decisions because of a lack of welllearned scripts or prescribed sets of procedures as described by Baron (2008:329). In small businesses worldwide, most new entrants to retailing lack relevant knowledge and have to learn the trade through experience (Choto, Tengeh \& Iwu 2014:93-94; Lebusa 2013:76; Malebana \& Swanepoel 2015:109; Stokes \& Wilson 2010:387) or through mentorship by older, established counterparts (Matabooe, Venter \& Rootman 2016:2). Equipping small township business owners or managers with the necessary managerial skills and knowledge has been identified as one of the key focus areas of South Africa's National Development Plan of 2030 (National Planning Commission 2012).

This article will specifically focus on the management of small business's inventory decisions. Research performed by Cant, Wiid and Kallier (2015:622) among small businesses found that small business failure can, among others, be attributed to a lack of product demand, product variety, product quality and strategic planning amid a changing economic climate and competition. These findings support the notion by Chopra and Meindl (2016:32) that inventory decisions should be aligned with business strategies to ensure business success.

Considering the South African government's continued drive to develop small township retailers, the importance of retailers to provide customers with products or services, as well as the importance of managing inventory aligned with the selected supply chain strategy, the purpose of this article is firstly, to determine how small retailers operating within the boundaries of Soweto manage their inventory decisions considering the orientation of the supply chain strategy; and secondly, to investigate whether retail industries differ in terms of inventory decisions.

\section{Literature review}

In the introduction the importance of selecting appropriate business strategies as well as the alignment of these strategies were emphasised. Literature relevant to inventory management decision-making by owners or managers of small retailers in 
accordance with the orientation of the supply chain strategy is discussed subsequently.

In 1997, Fisher developed a revolutionary and basic framework for selecting the most appropriate supply chain strategy (i.e. being either more cost-efficient or more responsive) based on the type of product (functional or innovative) sold and the demand (certain or uncertain) for the product. Fisher's framework has been widely accepted and many authors have built on the framework to include other factors, such as product characteristics; the level of demand and supply uncertainties placed on the supply chain; customers' buying behaviour; the position of the supply chain member within the supply chain; order winners and order qualifiers; and the production process (Ambe 2012; Christopher \& Gattorna 2005; Christopher \& Towill 2002; Duarte \& Machado 2011; Gattorna 2010; Lee 2002; MartínezOlvera \& Shunk 2006). However, after examining literature relating to supply chain strategies, Soni and Kodali (2011:73-74) concluded that the majority of authors classify a supply chain strategy as essentially being orientated towards either responsiveness or cost-efficiency, which will be the viewpoint supported in this article.

A responsive supply chain strategy aims to meet consumers' needs as fast as possible, whereas a cost-efficient supply chain strategy aims to meet consumers' needs at the lowest possible cost. A supply chain strategy orientated towards cost-efficiency is focused on keeping costs low by advocating economies of scale and optimisation techniques. Economies of scale and optimisation techniques are aimed at ensuring the best capacity utilisation throughout the production and distribution processes (Fawcett, Ellram \& Ogden 2007:228; Monczka et al. 2016:636; Qrunfleh \& Tarafdar 2013:573). A supply chain strategy orientated towards responsiveness is focused on flexibility and speed. A responsive strategy may enable the business to adapt rapidly to market changes, although customers' needs should be known before action is taken (Fawcett et al. 2007:228; Merschmann \& Thonemann 2011:43; Morita et al. 2015:2; Qrunfleh \& Tarafdar 2013:573; Wieland \& Wallenburg 2012:890).

When analysing literature on inventory management typically performed by small retailers, their differing decision patterns confirm an inclination to be either costefficient or responsive when formulating their supply chain strategies. The orientation of the supply chain strategy determines how retailers decide on the average rate of purchasing inventory, the amount of inventory purchased, as well as the quality and variety of products offered to customers (Bressler 2012:2; Chopra \& Meindl 2016:62-63; Hatten 2012:169; Ligthelm 2010:147).

When ordering inventory, managers must first consider the amount and frequency of inventory that is required (Islam et al. 2013:3-4). Businesses that purchase inventory in large batches to take advantage of economies of scale experience decreased production, transportation, ordering and purchasing costs (thus, increased cost-efficiency). Although purchasing inventory in large batches decreases costs, managers should be aware of the cost increase in carrying a large amount of inventory (Chopra \& Meindl 2016:62, 280). On the other hand, ordering inventory frequently and in small batches may ensure that retailers have ample inventory available to customers on demand (thus, increased responsiveness). Small businesses in townships usually search for the lowest prices from suppliers to offer a lower competing price to their customers (World Bank 2014:173). Some township businesses are known to coordinate orders when buying in bulk in order to cumulatively gain the advantage of economies of scale (World Bank 2014:173).

Holding additional inventory buffers against unpredictable customer demand (Baker \& Canessa 2009:425; Bowersox et al. 2013:48); however, owners or managers should carefully determine the number of inventory items held, because a surplus would lead to markdowns to generate sales. Not only will income be lost (because of the markdowns), but the carrying cost will decrease costefficiency (Graungaard Pedersen, Zachariassen \& Stentoft Arlbjørn 2012:354). On the other hand, insufficient inventory may decrease responsiveness and a consequent loss in sales (Baily et al. 2008:164). The decision to purchase additional inventory depends mainly on whether the small retailer views the increase in carrying cost worth having the products available when customer demand is higher. Therefore, purchasing additional inventory will increase the retailer's level of responsiveness at the expense of the level of cost-efficiency (Chopra \& Meindl 2016:63).

Because retailers are the final link in the supply chain, it is imperative that they are located conveniently near the place where customers want to purchase items (Scarborough 2012:539). Retailers should provide customers with the most convenient shopping experience and according to Prinsloo (2014:2) convenient shopping at local retailers implies more frequent shopping of quality and variety products in smaller grocery baskets. Although providing customers with superior (high-quality) product selection, service and variety increases costs, such an offering can provide small retailers with a competitive advantage (Hatten 2016:14, 296-297). Because of their exposure to increased variety offered by competing businesses, township buyers have developed into more selective buyers who no longer opt for downscaled or low-quality products (Petousis 2014). Providing a variety of products or high-quality (superior) items decreases the retailer's cost-efficiency as storage and inventory costs will increase.

In order to determine how small township retailers make inventory decisions in terms of responsiveness and costefficiency, the management of inventory by small township retailers were empirically researched.

\section{Research methodology}

In 2014, among a sample of 650 formal independent small businesses operating within Soweto, a survey was conducted 
on the management practices implemented by the owners or managers of these businesses. The survey was conducted among formal small businesses. Formal small businesses - of which the majority of small businesses operating within Soweto can be classified as (Njiro, Mazwai \& Urban 2010:3) form part of the registered business infrastructure of South Africa, which pay taxes and other levies to different levels of government (Du Plessis, Strydom \& Jooste 2012:56; Ligthelm 2013:59; Strydom 2015:464). Because the majority of previous studies (Badenhorst-Weiss, Cilliers \& Eicker 2014; Nkosi, Bounds \& Goldman 2013; Olawale \& Garwe 2010; Strydom 2013, 2015) conducted within townships were focused on formal small business because of the notion that informal small township businesses are unsuccessful and unproductive, the focus of this research is on formal small businesses operating within Soweto. Table 1 provides a summary of the research methodology used to conduct the 2014 Soweto study.

The empirical findings on the data relating to inventory presented in this article are based on the responses of the 556 formal independent small retailers (hereafter referred to as small retailers). The next section is structured to present the descriptive findings of the responses pertaining to the inventory decisions, whereafter the inferential findings are presented to determine whether the industry in which small retailers operate influences their responses in terms of the different inventory decisions.

\section{Empirical findings}

Throughout the empirical findings, reference is made to the findings of a study conducted by the World Bank in 2014 on the economies of South African townships. Because this World Bank study is regarded by the Gauteng Department of Economic Development (2014:9) as the most intensive study on South African townships to date, its findings are also

TABLE 1: Research methodology used to conduct the 2014 Soweto study.

\begin{tabular}{|c|c|}
\hline Research aspect & Description of empirical research aspect in this study \\
\hline Survey population & $\begin{array}{l}\text { The sample of } 650 \text { formal independent small business } \\
\text { included businesses situated in shopping malls, large } \\
\text { shopping areas (outside shopping malls), smaller shopping } \\
\text { areas, stand-alone businesses and industrial areas with 2-5, } \\
6-10 \text { and } 10-\text { plus surrounding businesses, but excluded } \\
\text { chain stores, franchises, street and in-home businesses. }\end{array}$ \\
\hline Sampling method & Probability sampling using a stratified sampling method. \\
\hline Sampling technique & Multistage quota sampling methodology. \\
\hline Sampling selection & $\begin{array}{l}\text { A list of } 650 \text { formal independent small businesses } \\
\text { operating within the boundaries of Soweto was } \\
\text { compiled by the Bureau of Market Research (BMR) in } \\
2012 \text { and was used as the sample frame for this research } \\
\text { ( } 2014 \text { ). If a business closed down during the } 2 \text {-year } \\
\text { period, fieldworkers were instructed to select any } \\
\text { business in the same residential area that complied } \\
\text { with all the requirements mentioned above. }\end{array}$ \\
\hline Sample units & Business owners or managers. \\
\hline Primary data collection & Interviewer-administrated questionnaires. \\
\hline Research instrument & $\begin{array}{l}\text { Structured interviewer-completed questionnaires } \\
\text { consisting of close-ended questions. }\end{array}$ \\
\hline $\begin{array}{l}\text { Classification of small } \\
\text { businesses }\end{array}$ & $\begin{array}{l}\text { Of the } 650 \text { formal independent small businesses, } 556 \text { were } \\
\text { classified as retailers based on the Standard Industrial } \\
\text { Classification. }\end{array}$ \\
\hline Analysis of data & $\begin{array}{l}\text { Both descriptive and inferential analyses were conducted } \\
\text { on the data. }\end{array}$ \\
\hline Ethical considerations & $\begin{array}{l}\text { The fieldwork was conducted within the directives of the } \\
\text { ethical policy of the University. }\end{array}$ \\
\hline
\end{tabular}

presented to elucidate the environment in which these township businesses operate and how township businesses are typically managed. Before the empirical findings are discussed, a profile of the 556 small retailers in terms of their survival is provided.

\section{Profile of the small retailers}

Responses to questions on age and business performance were used to profile the retail businesses. In a question on business age, respondents had to indicate the number of years in operation, while the questions on business performance included a question on monthly business income and another question on change patterns of business income in the preceding year. From the 556 responses obtained, it was determined that $59.4 \%$ of businesses had survived for 5 years or longer, $55.2 \%$ of the businesses had an average turnover of between R5000.00 and R30 000.00 during the previous month and $73.4 \%$ respondents indicated that their businesses either maintained the status quo or showed turnover (income) growth during the previous year. These businesses' survival of 5 years and more amid challenging circumstances within the township is aligned with the measure of business success worldwide (Deakins \& Freel 2012:19; Lebusa 2013:76; Ligthelm 2008:49).

\section{Descriptive analyses of the data pertaining to inventory}

The descriptive findings of data gathered are discussed under four headings (based on the literature review), namely the average rate of purchasing inventory, the quantity of inventory purchased, the quality of inventory sold and lastly the variety of inventory held by these small retailers. Respondents were asked to indicate their level of agreement with regard to how frequently an inventory statement applies to them; their importance rating of certain inventory aspects; and their disagreement or agreement with various inventory statements.

\section{Average rate of purchasing inventory}

The average rate of purchasing inventory was established by examining the frequency distributions of questions relating to the purchasing patterns of the respondents. The respondents were also asked whether they could easily obtain more inventory from suppliers when they ran out of inventory (never, sometimes or always). Table 2 shows that two-thirds $(66.7 \%)$ of the respondents indicated that they can sometimes and always easily obtain more inventory from their suppliers if they run out of inventory. In this regard, the World Bank (2014:172) reported that retailers in townships generally find it easy to purchase inventory from their suppliers, as multiple suppliers are available to choose from. The ability to easily

TABLE 2: Respondents' rating on obtaining more inventory from suppliers.

\begin{tabular}{lccc}
\hline Inventory statement & \multicolumn{3}{c}{ Rating } \\
\cline { 2 - 4 } & Never & Sometimes & Always \\
\hline 'I can easily obtain more stock from my suppliers & 29.9 & 21.2 & 45.5 \\
if I run out of stock.' & & & \\
\hline
\end{tabular}


acquire more inventory from suppliers when necessary may thus increase the retailers' level of responsiveness.

When the respondents were asked how often, on average, they purchased inventory, a similar percentage $(64 \%)$ of the respondents indicated that they purchase inventory on a daily or weekly basis (see Table 3). A possible explanation for purchasing inventory on a daily or weekly basis can be ascribed to the lack of retail space within townships (World Bank 2014:46), which makes it difficult for retailers to store excess inventory. Other possible reasons for purchasing inventory on a daily or weekly basis may be attributed to, firstly, retailers avoiding the risk of running out of inventory, and secondly, the ease with which new inventory can be acquired from numerous suppliers. From the above result follows that purchasing inventory on a daily or weekly basis may increase the retailers' level of responsiveness.

\section{Quantity of inventory purchased}

The quantity of inventory purchased by the respondents was analysed by examining data obtained from the questions relating to the quantity of inventory that the respondents purchase. Tables 4 and 5 provide the frequency distributions for each statement.

When the respondents were asked whether they purchased less, or the exact amount, or more inventory than they sold within a month, $53.8 \%$ of the respondents indicated that they sometimes and always purchase less, 65.5\% indicated that they sometimes and always purchase the exact amount and $69.4 \%$ indicated that they sometimes and always purchase more (see Table 4).

TABLE 3: Respondents' rate of purchasing inventory.

\begin{tabular}{lcccc}
\hline Rate of purchasing inventory & Daily & Weekly & Monthly & $\begin{array}{c}\text { When I see that } \\
\text { my stock is low }\end{array}$ \\
\hline $\begin{array}{l}\text { 'How often, on average, do } \\
\text { you purchase inventory?' }\end{array}$ & 12.4 & 51.6 & 10.3 & 24.3 \\
\hline
\end{tabular}

TABLE 4: Respondents' ratings on inventory statements.

\begin{tabular}{lccc}
\hline Inventory statements & \multicolumn{3}{c}{ Rates } \\
\cline { 2 - 4 } & Never & Sometimes & Always \\
\hline $\begin{array}{l}\text { I purchase less stock than what I sell within } \\
\text { a month. }\end{array}$ & 43.5 & 32.6 & 21.2 \\
$\begin{array}{l}\text { I purchase the exact amount of stock that } \\
\text { I sell within a month. }\end{array}$ & 31.7 & 39.6 & 25.9 \\
$\begin{array}{l}\text { I purchase more stock than what I sell within } \\
\text { a month. }\end{array}$ & 27.9 & 36.3 & 33.1 \\
$\begin{array}{l}\text { It is too expensive for me to purchase more stock } \\
\text { than what I can sell within a month. }\end{array}$ & 27.5 & 31.5 & 38.1 \\
$\begin{array}{l}\text { I purchase more stock when it is on sale at } \\
\text { my suppliers. }\end{array}$ & 19.2 & 25.7 & 51.8 \\
$\begin{array}{l}\text { I purchase more stock when I have a sale in } \\
\text { my store. }\end{array}$ & 26.4 & 27.5 & 42.6 \\
$\begin{array}{l}\text { I make provision for the fluctuation in the demand } \\
\text { from my customers (e.g. Over Easter and Christmas). }\end{array}$ & 24.5 & 24.6 & 48.2 \\
\hline
\end{tabular}

TABLE 5: Respondents' level of agreement with the inventory statements.

\begin{tabular}{llllll}
\hline Inventory statements & \multicolumn{3}{c}{ Strongly disagree } & $\longrightarrow$ & Strongly agree \\
\hline $\begin{array}{l}\text { A product should be immediately available } \\
\text { to my customers when they want to buy it. }\end{array}$ & 0.7 & 0.7 & 2.3 & 21.9 & 72.8 \\
$\begin{array}{l}\text { My customers know that I will always have } \\
\text { enough stock. }\end{array}$ & 0.7 & 0.9 & 3.8 & 24.8 & 68 \\
\hline
\end{tabular}

Poor inventory management can be a possible reason for just more than half $(53.8 \%)$ of the respondents indicating that they sometimes and always purchase less inventory than they can sell within a month. Purchasing less inventory than they could sell within a month may decrease their level of responsiveness because they may not have a product when required by customers. The decision of the almost two-thirds $(65.5 \%)$ of respondents who indicated that they sometimes and always purchase the exact amount of inventory that they sell within a month, may be a result of the lack of storage space in townships (World Bank 2014:207). The finding that $69.4 \%$ of retailers sometimes and always purchase more inventory than they sell within a month can be explained by their decision to purchase inventory in large quantities in order to qualify for free delivery from suppliers (World Bank 2014:151-153). As mentioned in the literature review, small businesses could increase their level of cost-efficiency because of savings in transportation costs. However, owners or managers of small businesses should consider the cost of purchasing additional inventory (to qualify for the free delivery), which may exceed the saving on transportation costs. This imbalance in costs can result in the business eventually paying more for the additional inventory and ultimately decreasing the level of costefficiency.

More than two-thirds (69.6\%) of the respondents indicated that it was sometimes and always too expensive to purchase more inventory than can be sold within a month (see Table 4). These responses imply that respondents are aware of the costs involved when purchasing more inventory than required within a month. When the respondents were asked whether they purchased more inventory when it was on sale at their suppliers, more than half $(51.8 \%)$ of the respondents indicated that they always purchase more (see Table 4). The conclusion is that paying less for inventory will not only contribute to cost-efficiency because of a lower price per unit but also contribute to responsiveness because of excess inventory available.

The majority $(70.1 \%)$ of respondents indicated that they sometimes and always purchase more inventory when they have a sale in their stores (see Table 4). Purchasing more inventory when having a sale implies that the retailers make provision for increased customer demand. In line with this finding, $72.8 \%$ of respondents indicated that they sometimes or always make provision for fluctuation in customer demand during special times, such as Easter and Christmas (see Table 4). These responses indicate that the retailers are focused on responsiveness.

When the respondents were asked to rate their level of agreement (ranging from strongly disagree to strongly agree) with a statement on the immediate availability of a product to customers, the majority $(72.8 \%)$ indicated that they strongly agree (see Table 5). Having products immediately available to customers when they want to buy the items will increase the respondents' level of responsiveness. A similar percentage 
$(68 \%)$ of the respondents also indicated that they strongly agree that their customers know that they will always have enough inventory (see Table 5), indicating the retailers' perception of their customers' opinions on their ability to always stock sufficient inventory.

\section{Quality of inventory}

Respondents were asked to rate the importance (ranging from very unimportant to very important) of carrying quality products and offering enough product variety (see Table 6). The majority (73.2\%) of respondents rated carrying quality products as very important. According to the World Bank (2014:10, 268), residents in townships expect the same quality products from small retailers as from large retail groups, such as Shoprite and Pick n Pay. Because quality products are generally associated with higher prices, a decrease in retailers' cost-efficiency can be expected. Although quality products are generally associated with higher prices which decrease cost-efficiency, keeping such items ensures customer need-satisfaction (increased responsiveness).

\section{Inventory variety}

Respondents were asked to rate the importance (ranging from very unimportant to very important) of offering enough product variety to their customers (see Table 7). Of the respondents, $68.8 \%$ rated carrying enough product variety as very important, which is in contrast to a study conducted by Klemz, Boshoff and Mazibuko (2006:594) in an Eastern Cape township where businesses carry a narrow product offering. The conclusion from the above finding is that carrying enough product variety will increase a retailer's responsiveness because customer demand can be met.

To summarise, the descriptive analyses of the data on inventory regarding the trade-off between responsiveness and cost-efficiency confirm that formal independent small retail businesses operating in Soweto seem to focus more on responsiveness than cost-efficiency when managing inventory.

Fisher (1997:1-2) and Huddleston et al. (2009:66) agree that the type of product (or service) that a retailer offers greatly depends on the specific industry in which the retailer operates. Further inferential analyses were conducted to determine whether retail industries differ in terms of their inventory decisions.

TABLE 6: Respondents' importance rating of providing quality products to customers.

\begin{tabular}{llcccc}
\hline Inventory aspects & \multicolumn{4}{c}{ Percentages } \\
\cline { 2 - 6 } & \multicolumn{4}{c}{ Very unimportant $\leftrightarrow$ Very important } \\
\hline Quality products & 0.7 & 1.8 & 3.4 & 20.1 & 73.2 \\
\hline
\end{tabular}

TABLE 7: Respondents' importance rating of holding a variety of inventory.

\begin{tabular}{llcccc}
\hline Inventory aspects & \multicolumn{5}{c}{ Percentages } \\
\cline { 2 - 6 } & \multicolumn{5}{c}{ Very unimportant $\leftrightarrow$ Very important } \\
\hline Enough product variety & 0.5 & 1.1 & 4.1 & 24.6 & 68.9 \\
\hline
\end{tabular}

\section{Inferential analyses of the data pertaining to inventory}

To determine whether the industry in which the respondents operate influences their responses, the 556 respondents were divided into six industries based on the Standard Industrial Classification (SIC) (see Table 8).

The Kruskal-Wallis one-way analysis of variance by ranks test was used to analyse the ordinal data obtained by the questions pertaining to the management of inventory. If a statistically significant difference $(p \leq 0.05)$ was found between the six industry groups with regard to the responses relating to a specific question, only the industry with the highest mean rank was considered. If no statistically significant difference existed at the $5 \%$ level between the different industry groups with regard to a specific question, the industry group in which the respondents operate does not influence their responses; therefore, the mean ranks were not discussed. Five hypotheses were formulated to determine whether a difference exists between the six industry groups with regard to the management of inventory.

\section{Hypothesis 1 - Average rate of purchasing inventory}

The first hypothesis was formulated in order to determine if a difference exists between the six industry groups with regard to how often (daily, weekly, monthly, when they see their stock is low), on average, they purchase inventory. The hypothesis was formulated as follows:

$\mathbf{H}_{1}$ : There is a difference between the industry groups with regard to how frequently (daily, weekly, monthly, when they see their stock is low), on average, they purchase inventory.

The results of the Kruskal-Wallis test in terms of Hypothesis 1 are shown in Table 9.

The results show that a statistically significant difference exists at the $1 \%$ level of significance $(p$-value $<0.01$ ) between the different industry groups with regard to how often, on average, they purchase inventory. This means that the six industries differ with regard to how often, on average, they purchase inventory.

TABLE 8: Classification of respondents into industries according to the Standard Industrial Classification.

\begin{tabular}{lc}
\hline Industry & $\begin{array}{c}\text { Number of respondents } \\
\text { within industry }\end{array}$ \\
\hline Grocery stores & 209 \\
Hardware stores & 42 \\
General stores & 88 \\
Retail services (such as hairdressers and undertakers) & 142 \\
Eating and drinking places & 39 \\
Sale, maintain and repair of vehicles and retail auto $\dagger$ & 36 \\
\hline
\end{tabular}

$\dagger$, When reporting on the results of the retail group termed 'sale, maintain and repair of vehicles and retail auto' this group will be referred to as 'retail auto'.

TABLE 9: Kruskal-Wallis test results on Hypothesis 1.

\begin{tabular}{lccc}
\hline Inventory question & Chi-square & Df & $\begin{array}{c}\text { Asymptotic } \\
\text { significance }\end{array}$ \\
\hline How often, on average, do you purchase inventory? & 15.469 & 5 & 0.009 \\
\hline
\end{tabular}

Df, degrees of freedom. 
To further investigate the differences between the six industry groups with regard to how often, on average, the respondents purchase inventory, the mean ranks (provided in Table 10) were considered.

A low mean rank indicates that the industry group tends to purchase inventory on a daily basis, whereas a high mean rank indicates that the industry tends to purchase inventory only when the inventory level is low. The results indicate that retail hardware stores (mean rank $=308.25$ ) tend to purchase inventory only when inventory levels are low. Most probably, the products they sell are generally characterised as specialised and sometimes expensive, for example, bricks and cement. Generally, the demand for these specialised products are lower, compared to products in other industries; therefore, retail hardware stores may choose not to purchase more inventory than necessary, as this could increase costs (such as facility and inventory costs). From the above follows that retail hardware stores are more focused on cost-efficiency than responsiveness when making decisions on replenishing inventory.

\section{Hypothesis 2-Quantity of inventory purchased}

The second hypothesis was aimed at determining if a difference exists between the six industry groups with regard to their agreement on how frequently they purchase inventory; whether it is too expensive to purchase more inventory than they can sell within a month; the effort in obtaining inventory; and providing for fluctuating customer demand. The hypothesis was formulated as follows:

$\mathbf{H}_{2}$ : There is a difference between the industry groups with regard to their agreement on how frequently (never, sometimes, always) they

$\mathbf{H}_{2 \mathrm{a}}$ : purchase less stock than they can sell within a month

$\mathbf{H}_{2 \mathrm{~b}}$ : purchase the exact amount of stock that they sell within a month

$\mathbf{H}_{2 c}$ : purchase more stock than they sell within a month

$\mathbf{H}_{2 \mathrm{~d}}$ : find it too expensive to purchase more stock than they can sell within a month

$\mathbf{H}_{2 \mathrm{e}}$ : can easily obtain more stock from their suppliers if they run out of stock

$\mathbf{H}_{2 \mathrm{f}}$ : purchase more stock when it is on sale at their suppliers

$\mathrm{H}_{2 \mathrm{~g}}$ : purchase more stock when they have a sale in their stores

$\mathbf{H}_{2 \mathrm{~h}}$ : make provision for fluctuation in demand from their customers (e.g. over Easter and Christmas).

TABLE 10: Mean ranks for Hypothesis 1.

\begin{tabular}{lc}
\hline Industries & Mean ranks $\dagger$ \\
\hline Retail grocery & 265.50 \\
Retail hardware & 308.25 \\
Retail general store & 283.75 \\
Retail service & 285.73 \\
Eating and drinking places & 201.51 \\
Retail auto & 303.80 \\
\hline
\end{tabular}

$\dagger$, Mean ranks results based on the question: 'How often, on average, do you purchase inventory?'
The results of the Kruskal-Wallis test to determine whether there is a difference between the industry groups with regard to the agreement on how frequently the inventory statements apply to them are shown in Table 11.

The results show that no statistically significant difference exists at the $5 \%$ level of significance (all $p$-values $>0.05$ ) between the different industry groups with regard to their agreement on how frequently (never, sometimes, always) they:

$\mathrm{H}_{2 \mathrm{a}}$ : purchase less stock than they sell within a month

$\mathbf{H}_{2 b}$ : purchase the exact amount of stock that they sell within a month

$\mathbf{H}_{2 c}$ : purchase more stock than they sell within a month

$\mathbf{H}_{2 \mathrm{~d}}$ : find it too expensive to purchase more stock than they can sell within a month

$\mathbf{H}_{2 \mathrm{~g}}$ : purchase more stock when they have a sale in their stores.

The mean ranks are fairly similar and thus show a similar rating of agreement on how frequently these inventory statements apply to the industry group.

The results of the remaining inventory statements show that statistically significant differences exist at the $1 \%$ and $5 \%$ levels of significance $(p<0.01$ and $p<0.05)$ between the different industry groups with regard to their agreement on how frequently (never, sometimes, always) they:

$\mathbf{H}_{2 \mathrm{e}}$ : can easily obtain more stock from their suppliers if they run out of stock

$\mathbf{H}_{2 f}$ : purchase more stock when it is on sale at their suppliers

$\mathbf{H}_{2 \mathrm{~h}}$ : make provision for the fluctuation in demand from their customers (e.g. over Easter and Christmas).

To further investigate the differences between the six industries and their agreement on the three matters listed above, the mean ranks provided in Table 12 were considered.

When considering the mean ranks (see Table 12) it appears that retail hardware stores (mean rank $=300.21$ ) tend to easily obtain more inventory from suppliers when they run out of inventory more frequently than the other industry groups.

TABLE 11: Kruskal-Wallis test results on Hypothesis 2.

\begin{tabular}{|c|c|c|c|}
\hline Inventory statements & Chi-square & Df & $\begin{array}{l}\text { Asymptotic } \\
\text { significance }\end{array}$ \\
\hline I purchase less stock than what I sell within a month. & 9.081 & 5 & 0.106 \\
\hline $\begin{array}{l}\text { I purchase the exact amount of stock that } \\
\text { I sell within a month. }\end{array}$ & 2.961 & 5 & 0.706 \\
\hline I purchase more stock than what I sell within a month. & 3.897 & 5 & 0.564 \\
\hline $\begin{array}{l}\text { It is too expensive for me to purchase more stock } \\
\text { than what I can sell within a month. }\end{array}$ & 5.015 & 5 & 0.414 \\
\hline $\begin{array}{l}\text { I can easily obtain more stock from my suppliers } \\
\text { if I run out of stock. }\end{array}$ & 21.097 & 5 & 0.001 \\
\hline $\begin{array}{l}\text { I purchase more stock when it is on sale at my } \\
\text { suppliers. }\end{array}$ & 29.711 & 5 & 0.000 \\
\hline I purchase more stock when I have a sale in my store. & 10.841 & 5 & 0.055 \\
\hline $\begin{array}{l}\text { I make provision for the fluctuation in the demand } \\
\text { from my customers (e.g. over Easter and Christmas). }\end{array}$ & 15.081 & 5 & 0.010 \\
\hline
\end{tabular}

Df, degrees of freedom. 
TABLE 12: Mean ranks for Hypothesis 2.

\begin{tabular}{lccc}
\hline Industries & \multicolumn{3}{c}{ Mean ranks } \\
\hline Retail grocery & $288.50 \dagger$ & $286.60 \ddagger$ & $295.92 \S$ \\
Retail hardware & $300.21 \dagger$ & $281.04 \ddagger$ & $268.88 \S$ \\
Retail general store & $280.91 \dagger$ & $311.57 \ddagger$ & $262.17 \S$ \\
Retail service & $227.44 \dagger$ & $217.22 \ddagger$ & $244.17 \S$ \\
Eating and drinking places & $285.76 \dagger$ & $262.99 \ddagger$ & $289.42 \S$ \\
Retail auto & $224.49 \dagger$ & $251.00 \ddagger$ & $226.22 \S$ \\
\hline
\end{tabular}

$\dagger$, Mean ranks based on statement: ' I can easily obtain more stock from my suppliers if I run out of stock'.

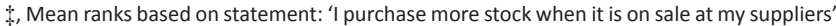
$\S$, Mean ranks based on statement: ' I make provision for the fluctuation in demand from my customers (e.g. over Easter and Christmas)'.

This finding can shed light on the previous finding (for Hypothesis 1) that retail hardware stores purchase inventory only when their inventory level is low. Both findings indicate that owners or managers of retail hardware stores tend to manage inventory more cost-efficiently.

Retail general stores tend to purchase more inventory more frequently when it is on sale at suppliers than the other industry groups, with a mean rank of 311.57. Purchasing more inventory at a lower price can increase the retail general store's cost-efficiency.

With a mean rank of 295.92, retail grocery stores tend to more frequently make provision for fluctuations in customer demand than the other industry groups. Retail grocery stores may be influenced more by special occasions, such as Easter and Christmas, than other industry groups, because special occasions are generally associated with higher consumption of food and beverages. By ensuring that they make provision for the fluctuation in customer demand, these stores can increase their level of responsiveness.

\section{Hypothesis 3 - Quantity of inventory purchased continued}

The purpose of the third hypothesis was to determine if a difference exists between the six industry groups with regard to their level of agreement on having products immediately available to customers and having their customers know that they will always have enough inventory. The hypothesis was formulated as follows:

$\mathbf{H}_{3}$ : There is a difference between the industry groups with regard to their level of agreement (strongly disagree to strongly agree) on whether

$\mathbf{H}_{3 \mathrm{a}}$ : they have products immediately available to customers when they want to buy it

$\mathbf{H}_{3 \mathrm{~b}}$ : their customers know that they will always have enough stock.

The results of the Kruskal-Wallis test are shown in Table 13.

The results show that no statistically significant difference exists at the $5 \%$ level of significance ( $p$-values $>0.05$ ) between the different industry groups with regard to the level of agreement on the two inventory statements in Hypothesis 3. The mean ranks are fairly similar and therefore indicate a similar rating between the different industry groups.
TABLE 13: Kruskal-Wallis test results on Hypothesis 3.

\begin{tabular}{lccc}
\hline Inventory statements & Chi-square & Df & $\begin{array}{c}\text { Asymptotic } \\
\text { significance }\end{array}$ \\
\hline $\begin{array}{l}\text { A product should be immediately available to } \\
\text { my customers when they want to buy it. }\end{array}$ & 2.112 & 5 & 0.833 \\
$\begin{array}{l}\text { My customers know that I will always have } \\
\text { enough stock. }\end{array}$ & 6.617 & 5 & 0.430 \\
\hline Df, degrees of freedom. & & &
\end{tabular}

\section{Hypothesis 4 - Quality of inventory}

The fourth hypothesis was aimed at determining if a difference exists between the six industries with regard to their importance rating on carrying quality products. The hypothesis was formulated as follows:

$\mathbf{H}_{4}$ : There is a difference between the industry groups with regard to their importance rating (very unimportant to very important) on carrying quality products.

The results of the Kruskal-Wallis test in terms of Hypothesis 4 are shown in Table 14.

The results show that no statistically significant difference exists at the $5 \%$ level of significance ( $p$-values $>0.05$ ) between the different industry groups with regard to the level of importance on carrying quality products. The mean ranks are fairly similar and therefore indicate a similar rating between the different industry groups with regard to the importance of carrying quality products.

\section{Hypothesis $\mathbf{5}$ - Inventory variety}

The fifth hypothesis was aimed at determining if a difference exists between the six industries with regard to their importance rating on having enough product variety. The hypothesis was formulated as follows:

$\mathbf{H}_{5}$ : There is a difference between the industry groups with regard to their importance rating (very unimportant to very important) on having enough product variety.

The results of the Kruskal-Wallis test in terms of Hypothesis 5 are shown in Table 15.

The results show that no statistically significant difference exists at the $5 \%$ level of significance $(p$-values $>0.05)$ between the different industry groups with regard to the level of importance on having enough product variety available to customers. The mean ranks are fairly similar and therefore indicate a similar rating between the different industry groups with regard to the importance of having enough product variety available to customers.

By examining the inferential analyses of the different industry groups in terms of inventory, it can be concluded that retail hardware stores manage inventory more costefficiently, because they tend to only purchase inventory when the level is low. Retail general stores take advantage of having capacity to store excess inventory by purchasing more inventory more frequently than other industry groups when a supplier has a sale. By paying less for inventory, retail general stores increase their cost-efficiency. By making 
provision for fluctuation in customer demand, retail grocery stores tend to be more responsive than other industry groups.

TABLE 14: Kruskal-Wallis test results on Hypothesis 4.

\begin{tabular}{lccc}
\hline Inventory aspects & Chi-square & Df & Asymptotic significance \\
\hline Quality products & 6.915 & 5 & 0.227 \\
\hline
\end{tabular}

Df, degrees of freedom.

TABLE 15: Kruskal-Wallis test results on Hypothesis 5.

\begin{tabular}{lccc}
\hline Inventory aspects & Chi-square & Df & Asymptotic significance \\
\hline Enough product variety & 4.776 & 5 & 0.444 \\
\hline
\end{tabular}

\section{Conclusion}

The importance of developing small township retail business remains a priority of the South African government. The value-adding role of retailers, as the final link in the supply chain, lies in offering an assortment of products (and services) in the right quantity at a convenient location to customers. Small business retailers' decisions on their market offering should revolve around sustaining their competitive advantage; therefore, retailers should analyse the industry in which they operate before making decisions relating to the product (or services) that they offer. The type

TABLE 16: Literature and empirical findings relating to the different inventory decisions.

\begin{tabular}{lll}
\hline Inventory decisions & \multicolumn{2}{c}{ Literature findings } \\
\cline { 2 - 3 } & $\begin{array}{l}\text { Supply chain orientated } \\
\text { towards responsiveness }\end{array}$ & $\begin{array}{l}\text { Supply chain orientated } \\
\text { towards cost-efficiency }\end{array}$ \\
\hline $\begin{array}{ll}\text { Average rate at which } \\
\text { retailers purchase }\end{array}$ & $\begin{array}{l}\text { Small batches of } \\
\text { inventory are ordered } \\
\text { inventory }\end{array}$ & $\begin{array}{l}\text { Large batches of } \\
\text { inventory are ordered } \\
\text { less frequently, in order } \\
\text { to benefit from } \\
\text { economies of scale. }\end{array}$
\end{tabular}

Empirical findings

Quantity of inventory purchased and held by retailers
Larger quantities of inventory are purchased regardless of the price to replenish inventory levels.

$\begin{array}{ll}\begin{array}{l}\text { Quantity of inventory } \\ \text { held by retailers }\end{array} & \begin{array}{l}\text { High inventory level } \\ \text { is maintained for } \\ \text { immediate satisfaction } \\ \text { of customer demand. }\end{array} \\ & \begin{array}{l}\text { A large amount of safety } \\ \text { and seasonal inventory is } \\ \text { held as provision is made } \\ \text { for fluctuating customer } \\ \text { demand. }\end{array}\end{array}$

Quality of inventory High-quality (superior)
items are offered to
customers usually
at a higher price.

Inventory variety usually from suppliers with the lowest price.
Larger quantities of inventory are purchased
No, or a small amount of, safety and seasonal inventory is held.

\section{Descriptive findings}

Retailers operating within Soweto manage their inventory responsively as they

have the ability to easily obtain more inventory from suppliers

- purchase inventory on a daily or weekly basis.

To conclude, the respondents' purchasing decisions in terms of the average rate at which they purchase inventory underline their orientation towards responsiveness.

Inferential findings

- The industry group in which the retailer operates influences how often, on average, they purchase inventory.

- Retail hardware stores tend to purchase inventory less often (only when their inventory leve is low) than the other industry groups.

\section{Descriptive findings}

The respondents' purchasing decisions in terms of the average amount of inventory that they purchase underline their orientation towards either responsiveness or cost-efficiency.

- Retailers operating within Soweto that manage their inventory more responsively: - purchase more inventory than they sell within a month

purchase more inventory when they have a sale in their stores.

- Retailers operating within Soweto who manage their inventory more cost-efficiently:

- find it too expensive to purchase more inventory than they sell within a month

purchase more inventory when items are on sale at suppliers.

Inferential findings

- The industry group in which the retailer operates does not influence how frequently they:

- purchase less inventory than they sell within a month

- purchase the exact amount of inventory that they sell within a month

- purchase more inventory than they sell within a month
find it too expensive to purchase more inventory than they sell within a month

- purchase more inventory when they have a sale in their stores.

- The industry group in which the retailer operates influences how frequently they:

- can easily obtain more inventory from suppliers if they run out of inventory

- purchase more inventory when it is on sale at their suppliers.

Retail hardware stores tend to easily obtain more inventory from their suppliers more frequently than the other industry groups.

Descriptive findings

- The respondents' purchasing decisions in terms of the average amount of inventory that they hold underline their orientation towards either responsiveness or cost-efficiency.

- Retailers operating within Soweto who manage their inventory more responsively:

- make provision for fluctuation in customer demand

- have products immediately available to a customer when they want to buy it

- believe that their customers are of the opinion that they will have enough inventory.

- To conclude, the respondents' purchasing decisions in terms of the quantity of inventory held shows their orientation towards responsiveness.

Inferential findings

- The industry group in which the retailer operates influences how frequently they make provision for fluctuation in customer demand.

- Retail grocery stores tend to make provision for fluctuation in demand from customers more frequently than the other industry groups.

- The industry group in which the retailer operates does not influence their level of agreement on having:

- a product immediately available to customers when they want to buy it

customers know that they will always have enough inventory.

\section{Descriptive findings}

Retailers operating within Soweto manage their inventory more towards responsiveness as they stock inventory of a high quality.

according to customers needs (although no downscaled products offered).

Inferential findings

The industry group in which the retailer operates does not influence the importance rating on carrying quality products.

Descriptive findings

Retailers operating within Soweto manage their inventory more towards responsiveness as they stock a variety of inventory.

Inferential findings

The industry group in which the retailer operates does not influence the importance rating on having enough product variety. 
of product (or service) that a retailer offers greatly depends on the specific industry in which the retailer operates and requires different management decisions.

Because inventory is one of the most expensive assets in many businesses, it should be managed with caution and owners or managers should consider the industry in which they operate based on its influence on the level of responsiveness and cost-efficiency at which the business should be managed. All inventory decisions should be aligned with the competitive strategy and different functional strategies (of which the supply chain strategy forms part). Based on the orientation of the supply chain strategy, retailers make inventory decisions relating to the average rate of purchasing inventory, the amount of inventory purchased as well as the quality and variety of products offered to customers.

The aim of this article was firstly, to determine how small retailers operating within the boundaries of Soweto manage their inventory decisions considering the orientation of the supply chain strategy; and secondly, to investigate whether retail industries differ in terms of inventory decisions. A literature study was conducted relating to the management decisions that owners or managers need to make taking into consideration the orientation of the supply chain strategy. Thereafter, a statistical analysis were conducted on the responses of 556 formal independent small retail businesses operating within Soweto to firstly determine the profile of these small retailers in terms of survival; secondly, how these small retailers currently manage their inventory decisions; and thirdly, whether retail industries differ in terms of inventory decisions. It was established that the small retailers are able to operate and survive despite the challenges of operating within a township as the majority of the small retailers showed growth in their annual income and have been in operation for 5 years or longer.

Table 16 summarises the literature and empirical findings of the inventory decisions that small retailers should make in terms of responsiveness and cost-efficiency.

From the descriptive findings presented in Table 16, it can be deduced that the majority of inventory decisions made by small township retailers are done responsively in order to serve the market with required offerings. The way in which these retailers perform inventory decision-making confirms the related literature findings presented. From the inferential findings presented, it can be concluded that, among industries, retail general stores are more inclined to make inventory decisions to increase their responsiveness, which suggests a supply chain strategy orientated towards responsiveness. In contrast, retail hardware stores are more cost-focused when making inventory decisions, which promotes a supply chain strategy orientated towards costefficiency. Hence, it is recommended that:

- The owners or managers of small township retailers need to be educated in terms of inventory management decisions. This article can be used as an educational platform to show how small township retailers can identify the aligned inventory decisions for supporting a selected supply chain strategy orientation.

- Generally, small township retailers may maintain their competitive advantage if they align all business strategies to promote responsiveness.

- Because the industry in which small retailers operate influences inventory management decisions in terms of responsiveness and cost-efficiency, owners or managers must consider the specific industry in which they operate before making such decisions.

\section{Future research}

The study can be replicated within other townships or developing countries with similar characteristics to compare their inventory decision-making behaviour. The influence of the other marketing mix variables (e.g. price) on inventory decisions should also be investigated to determine the interdependence between these variables. The influence of inventory management decisions on the survival of small retailers could also provide valuable insights. Lastly, the same study can be conducted within another industry, such as manufacturing or services.

\section{Acknowledgements Competing interests}

The authors declare that they have no competing interests with regard to the writing of this article.

\section{Authors' contributions}

T.E. is a lecturer and graduate student at the University of South Africa. This article is based on her Master's thesis completed in 2017. J.O.C. was the supervisor of T.E.'s Master's thesis and contributed to the conceptualisation of the article, as well as analysing and recording literature from the thesis.

\section{Disclaimer}

The views expressed in this article are those of the authors and not an official position of the institution.

\section{References}

Ambe, I.M., 2012, 'Determining an optimal supply chain strategy', Journal of Transport and Supply Chain Management 6(1), 126-147. https://doi.org/10.4102/jtscm. v6i1.35

Badenhorst-Weiss, J.A., Cilliers, J.O. \& Eicker, T., 2014, 'A unique market offering by formal independent retail and wholesale small businesses in Soweto township, South Africa', Problems and Perspectives in Management 12(4), 366-376.

Baily, P., Farmer, D., Crocker, B., Jessop, D. \& Jones, D., 2008, Procurement principles and management, 10th edn., Financial Times, Prentice Hall, Harlow.

Baker, P. \& Canessa, M., 2009, 'Warehouse design: A structured approach', European Journal of Operational Research 193(2), 425-436. https://doi.org/10.1016/j. ejor.2007.11.045

Baron, R.A., 2008, 'The role of affect in the entrepreneurial process', Academy of Management Review 33(2), 328-340. https://doi.org/10.5465/amr.2008.31193166

Bowersox, D.J., Closs, D.J., Cooper, M.B. \& Bowersox, J.C., 2013, Supply chain logistics management, 4th edn., McGraw-Hill Irwin, New York.

Bressler, M.S., 2012, 'How small businesses master the art of competition through superior competitive advantage', Journal of Management and Marketing Research 11, 2-9. 
Cant, M.C., Wiid, J.A. \& Kallier, S.M., 2015, 'Product strategy: Factors that influence product strategy decisions of SMEs in South Africa', Journal of Applied Business Research 31(2), 621-629. https://doi.org/10.19030/jabr.v31i2.9158

Chopra, S. \& Meindl, P., 2016, Supply chain management: Strategy, planning, and operation, 6th edn., Pearson, Harlow.

Choto, P., Tengeh, R.K. \& Iwu, C.G., 2014, 'Daring to survive or to grow? The growth aspirations and challenges of survivalist entrepreneurs in South Africa', Environmental Economics 7(4), 93-101.

Christopher, M. \& Gattorna, J., 2005, 'Supply chain cost management and value-based pricing', Industrial Marketing Management 34(2), 115-121. https://doi.org/ 10.1016/j.indmarman.2004.07.016

Christopher, M. \& Towill, D.R., 2002, 'Developing market specific supply chain strategies', International Journal of Logistics Management 13(1), 1-14. https:// doi.org/10.1108/09574090210806324

Coyle, J.J., Langley, C.J., Novack, B.J. \& Gibson, B.J., 2013, Managing supply chains: A logistics approach, 9th edn., South-Western/Cengage, Mason, $\mathrm{OH}$.

Deakins, D. \& Freel, M., 2012, Entrepreneurship and small firms, 6th edn., McGraw-Hill Higher Education, Berkshire.

Duarte, S. \& Machado, V.C., 2011, 'Manufacturing paradigms in supply chain management', International Journal of Management Science and Engineering Management 6(5), 328-342.

Du Plessis, P.J., Strydom, J.W. \& Jooste, C.J., 2012, Marketing management, 6th edn., Juta, Cape Town.

Fawcett, S.E., Ellram, L.M. \& Ogden, J.A., 2007, Supply chain management: From vision to implementation, Pearson, Upper Saddle River, NJ.

Fisher, M.L., 1997, 'What is the right supply chain for your product?', Harvard Business Review, March-April, pp. 105-116.

Gattorna, J., 2010, Dynamic supply chains. Delivering value through people, 2nd edn., Financial Times, Prentice Hall, Harlow.

Gauteng Department of Economic Development, 2014, Gauteng Department of Economic Development revitalisation strategy, viewed 23 January 2016, from http://www.ecodev.gpg.gov.za/Documents/Draft\%20GTER\%20Strat.pdf

Graungaard Pedersen, S., Zachariassen, F. \& Stentoft Arlbjørn, J., 2012, 'Centralisation vs de-centralisation of warehousing: A small and medium-sized enterprise perspective', Journal of Small Business and Enterprise Development 19(2), 352-369. https://doi.org/10.1108/14626001211223946

Hatten, T.S., 2012, Principles of small business management, 5th edn., South-Western Cengage, Florence.

Hatten, T.S., 2016, Small business management, 6th edn., Cengage Learning, Ontario.

Huddleston, P., Whipple, J., Mattick, R.N. \& Lee, S.J., 2009, 'Customer satisfaction in food retailing: Comparing specialty and conventional grocery stores', Internationa Journal of Retail \& Distribution Management 37(1), 63-80. https://doi.org/ 10.1108/09590550910927162

Islam, D.M.Z, Meier, J.F, Aditjandra, P.T., Zunder, T.H. \& Pace, G., 2013, 'Logistics and supply chain management', Research in Transportation Economics 41(1), 3-16. https://doi.org/10.1016/j.retrec.2012.10.006

Klemz, B.R., Boshoff, C. \& Mazibuko, N.E., 2006, 'Emerging markets in black South African townships: Small local independently owned versus large nationa retailers', European Journal of Marketing 40(5/6), 590-610. https://doi.org/ 10.1108/03090560610657859

Lawrence, A.S., Sivakumar, B. \& Arivarignan, G., 2013, 'A perishable inventory system with service facility and finite source', Applied Mathematical Modelling 37(7), 4771-4786. https://doi.org/10.1016/j.apm.2012.09.018

Lebusa, M.J., 2013, 'The prospects of making small retail outlets in the townships aggressively competitive', Southern African Journal of Entrepreneurship and Smal Business Management 6, 75-86. https://doi.org/10.4102/sajesbm.v6i1.34

Lee, H.L., 2002, 'Aligning supply chain strategies with product uncertainties', California Management Review 44(3), 105-119. https://doi.org/10.2307/41166135

Leitner, K.H. \& Güldenberg, S., 2010, 'Generic strategies and firm performance in SMEs: A longitudinal study of Austrian SMEs', Small Business Economics 35(2) 169-189. https://doi.org/10.1007/s11187-009-9239-x

Ligthelm, A.A., 2008, 'The impact of shopping mall development on small township retailers', South African Journal of Economic and Management Sciences 11(1), 37-53. https://doi.org/10.4102/sajems.v11i1.376

Ligthelm, A.A., 2010, 'Entrepreneurship and small business sustainability', Southern African Business Review 14(3), 131-153.

Ligthelm, A.A., 2013, 'Confusion about entrepreneurship? Formal versus informal small businesses', Southern African Business Review 17(3), 57-75.

Malebana, M.J. \& Swanepoel, E., 2015, 'Graduate entrepreneurial intentions in the rural provinces of South Africa', Southern African Business Review 19(1), 89-111.
Martínez-Olvera, C. \& Shunk, D., 2006, 'Comprehensive framework for the development of a supply chain strategy', International Journal of Production Research 44(21), 4511-4528. https://doi.org/10.1080/00207540600621698

Matabooe, M.J., Venter, E. \& Rootman, C., 2016, 'Understanding relational conditions necessary for effective mentoring of black-owned small businesses: A South African perspective', Acta Commercii 16(1), 1-11. https://doi.org/10.4102/ac. v16i1.327

Merschmann, U. \& Thonemann, U.W., 2011, 'Supply chain flexibility, uncertainty and firm performance: An empirical analysis of German manufacturing firms', International Journal of Production Economics 130(1), 43-53. https://doi.org/ 10.1016/j.ijpe.2010.10.013

Monczka, R.M., Handfield, R.B. Giunipero, L.C. \& Patterson, J.L., 2016, Purchasing and supply chain management, 6 th edn., Cengage, Boston, MA.

Morita, M., Machuca, J.A., De Los Ríos, J.L.P. \& Flynn, E.J., 2015, 'Effects of supply chain strategy on product development', 22nd International Annual European Operations Management Association Conference (EurOMA), Switzerland, viewed 20 December 2015, from http://www.euroma2015.org/euromapapers/papers/ SCM42_33226.pdf

National Planning Commission, 2012, National development plan 2030: Our futureMake it work, The Presidency, Pretoria.

Njiro, E., Mazwai, T. \& Urban, B., 2010, 'A situational analysis of small businesses and enterprises in the townships of the Gauteng province of South Africa', The First International Conference of the Centre for Small Business Development, University of Johannesburg, Soweto, 27-28 January 2010, viewed 21 April 2016, from https://www.uj.ac.za/faculties/humanities/Department-ofSocial-Work/ Documents/Intro_Njiro MazwaiUrban.pdf

Nkosi, E., Bounds, M. \& Goldman, G., 2013, 'Skills required for the black-owned small enterprise in Soweto', Acta Commercii 13(1), 1-10. https://doi.org/10.4102/ac. v13i1.186

Olawale, F. \& Garwe, D., 2010, 'Obstacles to the growth of new SMEs in South Africa: A principal component analysis approach', African Journal of Business Management 4(5), 729-738.

Petousis, M., 2014, TGl enters townships, viewed 30 October 2106, from www. askafrika.co.za/sites/default/files/TGi\%20enters\%20townships.pdf

Prinsloo, D.A., 2014, 'Retail trends in a very dynamic South African market', Urban Studies, viewed 30 October 2016, from www.urbanstudies.co.za/retail-trends-ina-very-dynamic-south-african-market/

Qrunfleh, S. \& Tarafdar, M., 2013, 'Lean and agile supply chain strategies and supply chain responsiveness: The role of strategic supplier partnership and postponement', Supply Chain Management: An International Journal 18(6), 571-582.

Rogerson, C.M. \& Rogerson, J.M., 1997, 'The changing post-apartheid city: Emergent black-owned small enterprises in Johannesburg', Urban Studies 34(1), 85-103. https://doi.org/10.1080/0042098976285

Scarborough, N.M., 2012, Effective small business management, 10th edn., Pearson Prentice Hall, Upper Saddle River, NJ.

Soni, G. \& Kodali, R., 2011, "The strategic fit between "competitive strategy" and "supply chain strategy" in Indian manufacturing industry: An empirical approach', Measuring Business Excellence 15(2), 70-89. https://doi.org/10.1108/ 1368304111113163

South Africa, 2004, National Small Business Amendment Act of the Republic of South Africa, no. 29, Pretoria Government Printer, viewed 17 April 2014, from https:// www.thedti.gov.za/business_regulation/acts/small_business_amendment_ act.pd

Stokes, D. \& Wilson, N., 2010, Small business management and entrepreneurship, 7th edn., Cengage Learning EMEA, Hampshire.

Strydom, J.W., 2013, 'Retail patronage of Sowetan consumers after 1994', African Journal of Business Management 7(29), 2863-2871. https://doi.org/10.5897/ AJBM12.1133

Strydom, J.W., 2015, 'David against Goliath: Predicting the survival of formal small businesses in Soweto', International Business \& Economics Research Journal 14(3), 463-476. https://doi.org/10.19030/iber.v14i3.9210

Walker, E., Redmond, J., Webster, B. \& Le Clus, M., 2007, 'Small business owners: Too busy to train?', Journal of Small Business and Enterprise Development 14(2), 294306. https://doi.org/10.1108/14626000710746718

Wieland, A. \& Wallenburg, C.M., 2012, 'Dealing with supply chain risks: Linking risk management practices and strategies to performance', International Journal of Physical Distribution \& Logistics Management 42(10), 887-905. https://dol org/10.1108/09600031211281411

Wisner, J.D., Tan, K.C. \& Leong, G.K., 2016, Supply chain management: A balanced approach, 4th edn., South-Western, Boston, MA.

World Bank, 2014, Economics of South African townships: Special focus on Diepsloot The World Bank, Washington, DC. 